\title{
The amino acid sequence of the cytochrome $c_{2}$ from the phototrophic bacterium Rhodopseudomonas globiformis
}

\author{
R. P. AMBLER, ${ }^{\S}$ T. E. MEYER, $\dagger$ M. A. CUSANOVICH† and M. D. KAMEN $\ddagger$ \\ *Department of Molecular Biology, University of Edinburgh, Edinburgh EH9 3JR, Scotland, U.K., †Department of Biochemistry, \\ University of Arizona, Tucson, AZ 85721, U.S.A., and $\$ 1390$ Plaza Pacifica, Montecito, CA 93108, U.S.A.
}

\begin{abstract}
The amino acid sequence of the principal soluble cytochrome $c$ from the phototrophic acidophilic bacterium Rhodopseudomonas (or Rhodopila) globiformis was determined. By the criteria of percentage sequence identity and fewness of internal insertions and deletions it is more similar in sequence to some mitochondrial cytochromes $c$ than to any known bacterial cytochrome. The organism does not have any properties that commend it as being particularly similar to postulated prokaryotic precursors of the mitochondrion. We consider that the relatively high degree of sequence similarity is an instance of convergence, and is an example of the limitations that are imposed on attempts to deduce distant evolutionary relationships from sequence information. Detailed evidence for the amino acid sequence of the protein has been deposited as Supplementary Publication SUP 50136 (12 pages) at the British Library Lending Division, Boston Spa, West Yorkshire LS23 7BQ, U.K., from whom copies are available on prepayment [see Biochem. J. (1987) 241, 5].
\end{abstract}

\section{INTRODUCTION}

The purple phototrophic bacteria are a readily definable group of organisms, as they possess a characteristic mode of energy metabolism mediated by easily recognizable bacteriochlorophyll pigments and soluble electron-transport proteins. However, they vary greatly in their cellular morphology and in the appearance of their photosynthetic membranes, and in sequences of macromolecules. The group is being used as a test system for the exploration of the validity of using sequence information for constructing natural classifications of prokaryotes (Ambler et al., 1979a,b; Dickerson, 1980; Woese et al., 1984; Meyer et al., 1986). Sequence results have also been interpreted as showing that the purple phototrophic bacteria are closely related to the prokaryote that is supposed to have been the mitochondrial ancestor (Dayhoff \& Schwarz, 1981).

Rhodopseudomonas globiformis (Pfennig, 1974) was isolated from a warm acidic sulphur spring in Yellowstone Park, and only this single strain of the organism has been recognized so far. Imhoff et al. (1984) have proposed that this organism should be put into a new genus, Rhodopila, as it is sufficiently different from all other purple phototrophic bacteria.

We have isolated the predominant soluble cytochrome $c$ from this organism, and determined its amino acid sequence. By the commonly used criteria of percentage sequence identity and number of insertions or deletions needed for optimal alignment we compare the sequence with those of mitochondrial cytochromes $c$ and other bacterial cytochromes.

\section{EXPERIMENTAL}

\section{Growth of organism}

Rps. globiformis strain 7950 (D.S.M. 161) was kindly provided by Dr. H. Biebl and Dr. N. Pfennig. It was grown phototrophically on the gluconate/mannitol medium recommended by Pfennig (1974) in 1-litre prescription bottles at $30^{\circ} \mathrm{C}$, and harvested after 3 days' growth, with a yield of about $2 \mathrm{~g}$ wet wt. of cells/1. Only about half the cultures grew at each transfer, and the cell yield was only about one-third of what we have come to expect from organotrophic purple bacteria.

\section{Purification of protein}

Wet cells $(1250 \mathrm{~g})$ were suspended in 4.5 litres of

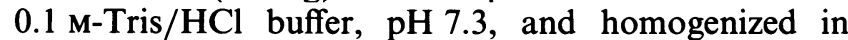
a Ribi cell fractionator operated at $137 \mathrm{MPa}$ $\left(20000 \mathrm{lbf} / \mathrm{in}^{2}\right)$. Almost all the membranes were removed by centrifugation at $145000 \mathrm{~g}$ for $4 \mathrm{~h}$. The supernatant was passed through a column $(15 \mathrm{~cm} \times 7 \mathrm{~cm}$ diam.) of Whatman DE-52 DEAE-cellulose equilibrated with $0.2 \mathrm{M}$-Tris $/ \mathrm{HCl}$ buffer, $\mathrm{pH}$ 7.3. Bacterial ferredoxin was adsorbed on the column, and eventually removed with $0.02 \mathrm{M}$-Tris/ $\mathrm{HCl}$ buffer, $\mathrm{pH} 7.3$, containing $0.5 \mathrm{M}-\mathrm{NaCl}$. The cytochrome fraction, not retarded by this column, was desalted by gel filtration through Sephadex G-25 into $0.001 \mathrm{M}$-Tris/ $\mathrm{HCl}$ buffer, $\mathrm{pH} \mathrm{8.0,} \mathrm{and} \mathrm{applied} \mathrm{to} \mathrm{a}$ column $(15 \mathrm{~cm} \times 7 \mathrm{~cm}$ diam. $)$ of Whatman DE-52 DEAE-cellulose equilibrated with the same buffer. A pink cytochrome band was adsorbed less tightly than the green band of the high-potential non-haem iron protein (HiPIP). The coloured bands were not resolved when the column was developed with a $0-0.1 \mathrm{M}-\mathrm{NaCl}$ gradient in

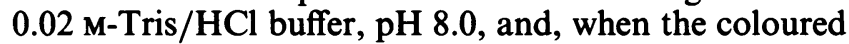
eluate was desalted and an attempt made to readsorb the proteins on DEAE-cellulose, only a portion would bind, and in very broad bands. The coloured material that did

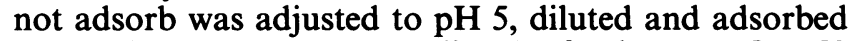
on a column $(15 \mathrm{~cm} \times 7 \mathrm{~cm}$ diam. $)$ of Whatman CM-52 CM-cellulose equilibrated with $0.01 \mathrm{M}$-potassium phosphate buffer, pH 5.0. The cytochrome was adsorbed more strongly than the HiPIP. The DEAE-cellulose and

\footnotetext{
Abbreviation used: HiPIP, high-potential non-haem iron protein.
}

$\S$ To whom correspondence should be addressed. 
Table 1. Amino acid composition of Rhodopseudomonas globiformis cytochrome $c_{2}$

Results are shown as mol of residues $/ \mathrm{mol}$, and were calculated on the basis that $\Sigma(\mathrm{Ala}+\mathrm{Leu}+\mathrm{Asp}+\mathrm{Glu}+\mathrm{Phe}+\mathrm{Lys}+$ His + Arg $)=(4+6+8+8+2+9+5+3)=45$. Values discarded because the hydrolysis conditions were not suitable for good recovery of the amino acid concerned are shown in parentheses. The 'best value' is the average of the acceptable estimates. Samples (2) and (5) were hydrolysed at $105^{\circ} \mathrm{C}$, the others (because of an oven fault; see the text) at about $100{ }^{\circ} \mathrm{C}$. All were hydrolysed with $6 \mathrm{M}-\mathrm{HCl}$ except sample (6), which was hydrolysed with $3 \mathrm{M}$-mercaptoethanesulphonic acid. Samples (2) and (6) were hydrolysed for $96 \mathrm{~h}$, the others for $24 \mathrm{~h}$. Samples (1), (2) and (6) and, in addition, sample (4) had been oxidized with performic acid and sample (5) aminoethylated.

\begin{tabular}{|c|c|c|c|c|c|c|c|c|}
\hline & \multicolumn{8}{|c|}{ Composition (mol of residue/mol) } \\
\hline & \multicolumn{6}{|c|}{ Hydrolysis and analysis } & \multirow{2}{*}{$\begin{array}{l}\text { 'Best } \\
\text { value' }\end{array}$} & \multirow[b]{2}{*}{ Sequence } \\
\hline & (1) & (2) & (3) & (4) & (5) & (6) & & \\
\hline $\begin{array}{l}\text { Glycine } \\
\text { Alanine } \\
\text { Valine } \\
\text { Leucine } \\
\text { Isoleucine }\end{array}$ & $\begin{array}{c}13.4 \\
4.2 \\
(4.1) \\
5.7 \\
(5.7)\end{array}$ & $\begin{array}{r}13.1 \\
4.1 \\
7.3 \\
5.9 \\
9.9\end{array}$ & $\begin{array}{c}13.2 \\
3.9 \\
(4.6) \\
5.7 \\
(5.8)\end{array}$ & $\begin{array}{c}12.9 \\
4.1 \\
(3.9) \\
\text { Lost } \\
\text { Lost }\end{array}$ & $\begin{array}{c}12.9 \\
3.9 \\
(5.9) \\
5.9 \\
(8.8)\end{array}$ & $\begin{array}{c}13.7 \\
4.1 \\
(4.4) \\
5.9 \\
(6.6)\end{array}$ & $\begin{array}{l}13.2 \\
4.1 \\
7.3 \\
5.8 \\
9.9\end{array}$ & $\begin{array}{r}13 \\
4 \\
7 \\
6 \\
10\end{array}$ \\
\hline $\begin{array}{l}\text { Serine } \\
\text { Threonine }\end{array}$ & $\begin{array}{l}6.0 \\
4.6\end{array}$ & $\begin{array}{l}(3.5) \\
(3.9)\end{array}$ & $\begin{array}{l}4.9 \\
4.8\end{array}$ & $\begin{array}{l}5.4 \\
4.9\end{array}$ & $\begin{array}{l}4.8 \\
4.7\end{array}$ & $\begin{array}{l}5.0 \\
5.0\end{array}$ & $\begin{array}{l}5.2 \\
4.8\end{array}$ & $\begin{array}{l}5 \\
5\end{array}$ \\
\hline $\begin{array}{l}\text { Aspartic acid } \\
\text { Asparagine } \\
\text { Glutamic acid } \\
\text { Glutamine }\end{array}$ & $\begin{array}{l}8.2 \\
7.9\end{array}$ & $\begin{array}{l}7.8 \\
7.9\end{array}$ & $\begin{array}{l}7.8 \\
7.8\end{array}$ & $\begin{array}{l}8.2 \\
8.0\end{array}$ & $\begin{array}{l}7.7 \\
7.9\end{array}$ & $\begin{array}{l}8.3 \\
8.2\end{array}$ & $\begin{array}{l}8.0 \\
8.0\end{array}$ & $\begin{array}{l}5 \\
3 \\
5 \\
3\end{array}$ \\
\hline $\begin{array}{l}\text { Phenylalanine } \\
\text { Tyrosine } \\
\text { Tryptophan }\end{array}$ & $\begin{array}{l}2.0 \\
5.8\end{array}$ & $\begin{array}{l}2.2 \\
5.7\end{array}$ & $\begin{array}{l}2.3 \\
5.7\end{array}$ & $\begin{array}{l}\text { Lost } \\
\text { Lost }\end{array}$ & $\begin{array}{c}2.0 \\
5.8 \\
(0.4)\end{array}$ & $\begin{array}{l}2.0 \\
6.0 \\
0.9\end{array}$ & $\begin{array}{l}2.1 \\
5.8 \\
0.9\end{array}$ & $\begin{array}{l}2 \\
6 \\
1\end{array}$ \\
\hline $\begin{array}{l}\text { Cysteine } \\
\text { Methionine }\end{array}$ & 0.8 & 1.0 & 1.1 & $\begin{array}{l}1.9^{*} \\
1.1 \ddagger\end{array}$ & $\begin{array}{l}1.9 \dagger \\
1.0\end{array}$ & 1.0 & $\begin{array}{l}1.9 \\
1.0\end{array}$ & $\begin{array}{l}2 \\
1\end{array}$ \\
\hline Proline & 9.9 & 10.4 & 10.7 & 10.6 & 10.6 & $(10.5)$ & 10.4 & 11 \\
\hline $\begin{array}{l}\text { Lysine } \\
\text { Histidine } \\
\text { Arginine }\end{array}$ & $\begin{array}{l}8.6 \\
4.8 \\
3.1\end{array}$ & $\begin{array}{l}9.1 \\
5.1 \\
2.8\end{array}$ & $\begin{array}{l}9.0 \\
5.4 \\
3.2\end{array}$ & $\begin{array}{l}7.6 \\
5.0 \\
2.5\end{array}$ & $\begin{array}{l}9.2 \\
5.2 \\
3.2\end{array}$ & $\begin{array}{l}8.0 \\
5.0 \\
2.7\end{array}$ & $\begin{array}{l}8.6 \\
5.1 \\
2.9\end{array}$ & $\begin{array}{l}9 \\
5 \\
3\end{array}$ \\
\hline Total & & & & & & & & 106 \\
\hline
\end{tabular}

CM-cellulose were extruded from their columns, and the HiPIP and cytochrome bands were cut out and eluted separately with $0.5 \mathrm{M}-\mathrm{NaCl}$ in $\mathrm{pH} \mathrm{7.3} \mathrm{Tris} \mathrm{buffer.} \mathrm{The}$ proteins were next precipitated with $\left(\mathrm{NH}_{4}\right)_{2} \mathrm{SO}_{4}$. HiPIP was precipitated in the $60-90 \%$-saturated fraction, and the cytochrome in the $40-60 \%$-saturated fraction. When redissolved, the $\left(\mathrm{NH}_{4}\right)_{2} \mathrm{SO}_{4}$-precipitated fractions were extremely viscous. We believe that the explanation for the unsatisfactory chromatography of the proteins on DEAE-cellulose was the presence in the Rps. globiformis cell extracts of large amounts of acidic polysaccharide.

The cytochrome and HiPIP fractions were subjected to gel filtration through a column $(100 \mathrm{~cm} \times 8 \mathrm{~cm}$ diam. $)$ of Sephadex G-75 (40-120 mesh) in $0.02 \mathrm{M}-\mathrm{Tris} / \mathrm{HCl}$ buffer, pH 7.3, containing $0.1 \mathrm{M}-\mathrm{NaCl}$. The cytochrome appeared to be slightly larger than the HiPIP, and they partially separated, but the 'polysaccharide' caused streaking and poor separation on the column if the viscosity was not greatly reduced by dilution before application of the sample to the column.

The cytochrome sample was desalted through Sephadex G-25, and adsorbed on CM-cellulose equilibrated with $0.01 \mathrm{M}$-potassium phosphate buffer, pH 5. An attempt was made to oxidize the cytochrome on the column by passing through some $0.001 \mathrm{M}-\mathrm{K}_{3} \mathrm{Fe}(\mathrm{CN})_{6}$, but when the cytochrome was eluted with a linear gradient of $0.01-0.05 \mathrm{M}$-potassium phosphate buffer, pH 6, it was still partly reduced. The CM-cellulose chromatography was repeated, and the resulting product was $20 \mu \mathrm{mol}$ of cytochrome $c$ with a purity index $\left(A_{280} / A_{417}\right)$ of 0.18 , with a yield of about $50 \%$ as judged by the spectrophotometric estimate of the cytochrome $c$ content of the supernatant from the initial cell extract. About $15 \mu \mathrm{mol}$ of HiPIP of purity index $\left(A_{280} / A_{390}\right)$ of 1.8 was also recovered.

Despite the interference of the 'polysaccharide', the chromatographic behaviour of the cytochrome fraction suggested that the great majority of the material was of a single molecular species. The final preparation had an $\alpha$-band maximum of $551 \mathrm{~nm}$, an $A_{551 \text { (reduced) }} / A_{280}$ ratio of 1.3 , and gave a single band of $M_{\mathrm{r}}$ about 11000 when examined by SDS/polyacrylamide-gel electrophoresis. It also gave only a doublet (oxidized and reduced forms) when subjected to fast protein liquid chromatography on a Mono-Q column in $0.02 \mathrm{M}$-sodium acetate buffer, pH 5.5, with a $0-0.5 \mathrm{M}-\mathrm{NaCl}$ gradient. 


\section{Amino acid sequence determination}

The methods used have been described before (Ambler \& Wynn, 1973; Ambler et al., 1979c, 1984). The $\mathrm{N}$-terminal sequence of the protein was examined with an automatic sequencer (Beckman model 890A) using a DMBA program (Beckman 102473). Amide groups were assigned from peptide electrophoretic mobilities and exopeptidase analysis. One peptide was subdigested with the proteinase from a mutant strain of Pseudomonas fragi (Drapeau, 1980) that specifically hydrolyses peptide bonds on the $N$-terminal side of aspartic acid and cysteic acid residues.

\section{RESULTS}

The amino acid composition of Rps. globiformis cytochrome $c_{2}$ is shown in Table 1 . The evidence for the proposed amino acid sequence is summarized in Fig. 1. Details of the purification, analysis and sequence determination experiments on the peptides are given in Supplementary Publication SUP 50136. The criteria for satisfactory results and the nature and the format of the Supplementary Publication are given in previous papers (Ambler \& Wynn, 1973; Ambler et al., 1979c).

The amino acid sequence was deduced by characterizing peptides from four separate digests of the cytochrome, from which the haem had been removed before digestion, except in the case of the $\mathrm{CNBr}$ experiment. These digests were: (a) $2.3 \mu \mathrm{mol}$, digested with trypsin; (b) $1.7 \mu \mathrm{mol}$, treated with $\mathrm{CNBr}$ (native protein was used, to minimize operations that could result in partial oxidation of methionine residues); (c) $2.1 \mu \mathrm{mol}$, digested with chymotrypsin; (d) $2.2 \mu \mathrm{mol}$, digested with trypsin, after treatment with ethyleneimine under reducing conditions.

\section{DISCUSSION}

\section{Accuracy of proposed sequence}

In contrast with the purification of the protein, the determination of the amino acid sequence presented no particular difficulties. The peptides characterized are linked into a single sequence by good overlaps, and peptides accounting for the complete sequence were found in each digest. For no part of the proposed sequence does the evidence seem to be markedly weak. The general reliability of the procedures used has been demonstrated in a number of cases where amino acid sequences have been subsequently confirmed by DNA sequencing (e.g. Daldal et al., 1986).

\section{Structural affinities of the Rps. globiformis cytochrome $c_{2}$}

The amino acid sequence (Fig. 1) is that of a 'small' cytochrome $c_{2}$, like those of Rhodomicrobium vannielii or Rhodopsueodomonas viridis (Ambler et al., 1976), those of some other members of the Rhodospirallaceae (Ambler et al., 1979a) and cytochromes from two non-phototrophic bacteria, Agrobacterium tumefaciens (Van Beeumen et al., 1980) and Nitrobacter agilis (Tanaka et al., 1982). The 'small' cytochromes $c_{2}$ are close in sequence to mitochondrial cytochromes $c$, and can be aligned to give good matching throughout the sequences with only the need for a very small number of insertions or deletions. A simple measure of the degree of similarity between related sequences is given by the

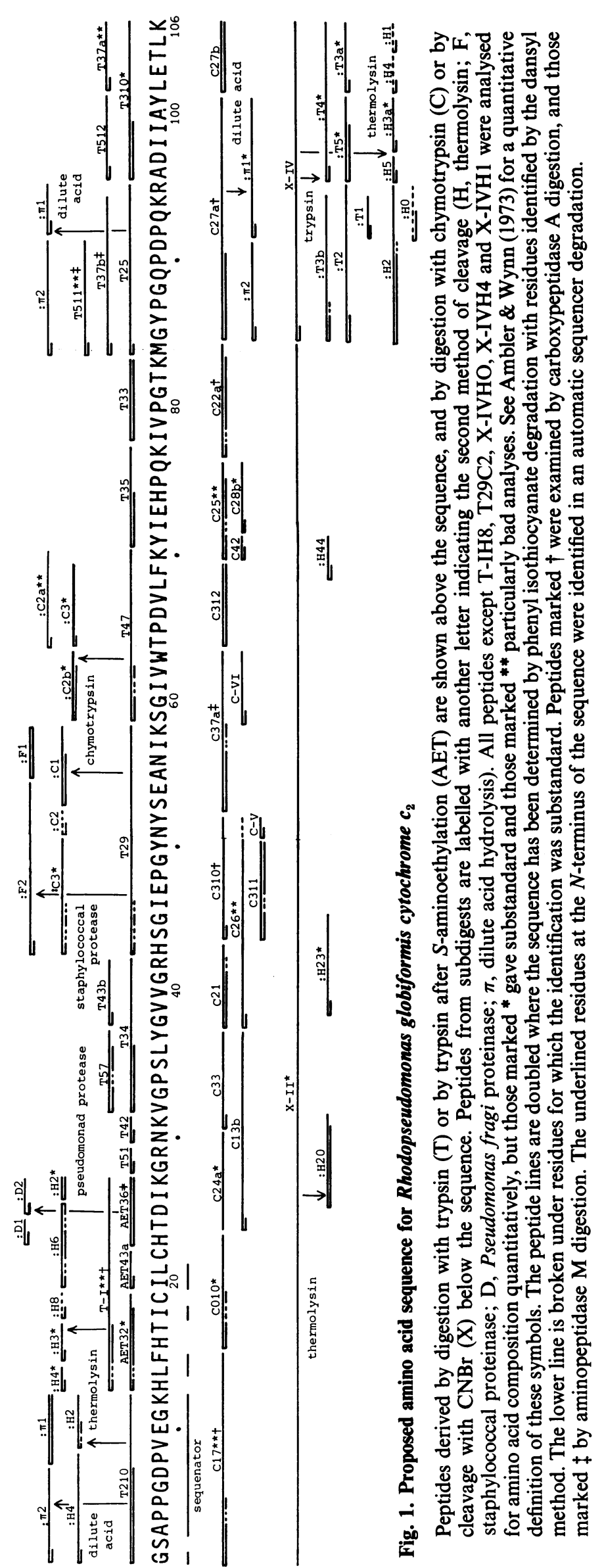


Table 2. Similarity matrix showing percentage sequence identity between cytochromes $c$

The sequences are aligned as shown in Fig. 3 of Meyer \& Kamen (1982) except that no gap is placed between residues 77 and 78 of the mitochondrial sequences and the corresponding bacterial ones. The score is the percentage identity between pairs of sequences only counting positions that are occupied in both sequences, taking no account of insertions or deletions, or of extra residue on ends. The sequences are given in Meyer \& Kamen (1982), apart from those of Enteromorpha intestinalis (Meatyard \& Boulter, 1974), Nitrobacter agilis (Tanaka et al., 1982) and Aquaspirillum itersonii (Woolley, 1987). Identity values of greater than $50 \%$ are shown in large numerals.

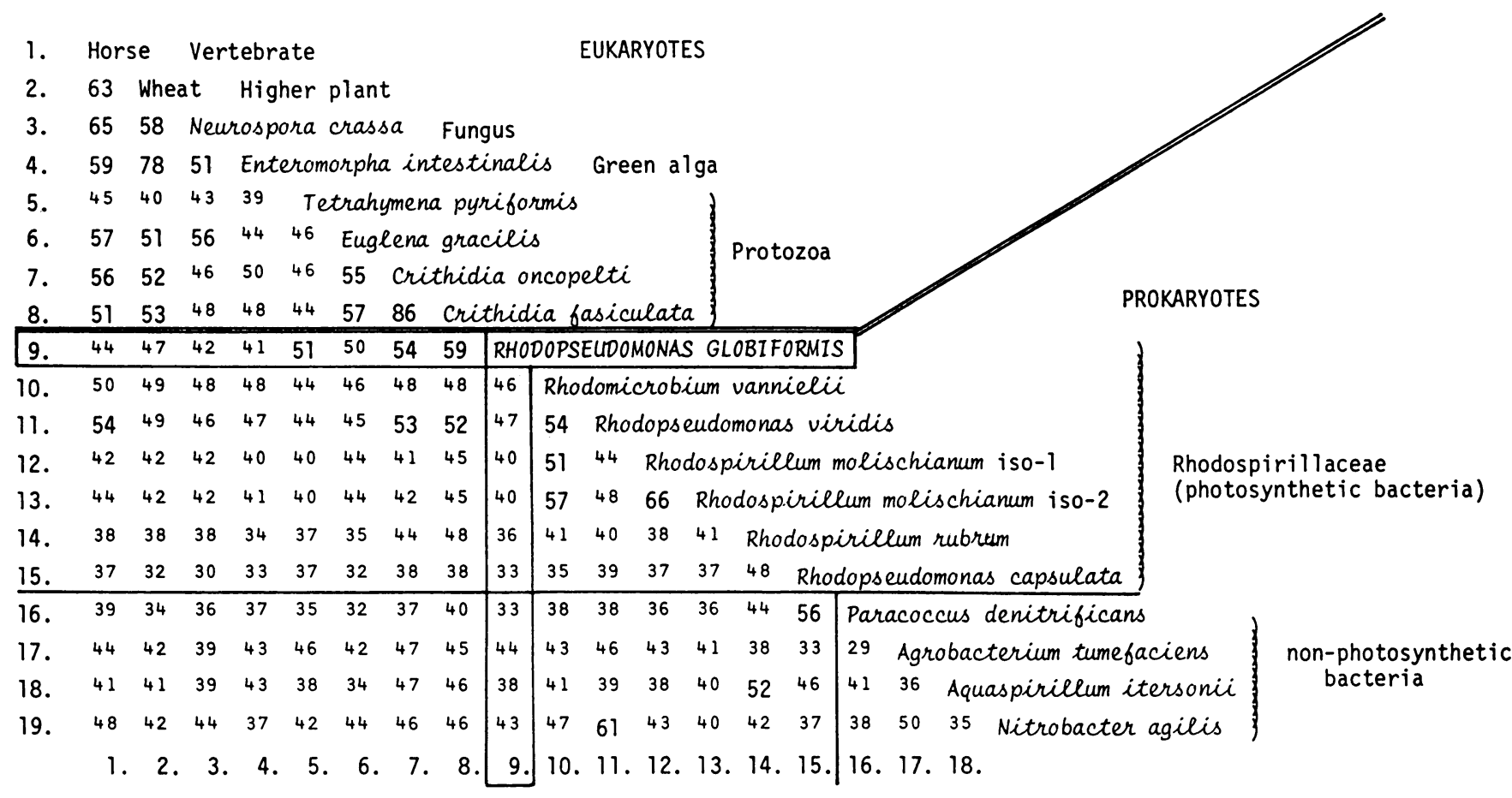

percentage identity when the sequences are aligned so as to match optimally, and Table 2 gives a comparison matrix that relates the Rps. globiformis sequence to a range of mitochondrial and bacterial cytochromes $c$. The organisms chosen for inclusion in Table 2 were selected so as to include a wide range of eukaryotes and non-phototrophic bacteria, and a representative range of the Rhodospirillaceae, although excluding cytochromes that were very different in sequence, and not in the cytochrome $c_{2}$ sequence class.

By the criteria used in Table 2, the Rps. globiformis sequence is more similar to those of some of the mitochondrial proteins than it is to any of the bacterial proteins considered. The greatest similarity is to the sequence of the mitochondrial cytochrome $c-556$ from the zooflagellate protozoon Crithidia fasciculata (Hill \& Pettigrew, 1975) (Fig. 2).

More sophisticated methods of comparison have also been used to try to relate the Rps. globiformis sequence to those of other cytochromes $c$ (Dayhoff \& Schwartz, 1981; Barnabas et al., 1982; Dayhoff, 1983). Dayhoff interpreted the similarities as evidence that mitochondria had arisen from prokaryotes independently on more than one occasion, and constructed trees suggesting the lines in which these events might have occurred.

\section{'But only God can make a tree' (Kilmer, 1913)}

Woese and his associates have been attempting to deduce the affinities of the prokaryotic ancestor of the mitochondrion by comparing $16 \mathrm{~S}$ rRNA catalogues (Fox et al., 1977) or complete $16 \mathrm{~S}$ rRNA sequences (Yang et al., 1985). They speculate that the ancestor was a member of their $\alpha$ group of purple bacteria (Woese et al., 1984), which embraces all the bacteria shown in Table 2. The results of comparing five different bacterial $16 \mathrm{~S}$ rRNA sequences with mitochondrial $16 \mathrm{~S}$ rRNA sequences (Yang et al., 1985) showed that it was difficult to demonstrate that any one of the bacterial groups was the obvious ancestor. However, they managed to work out methods of adjusting the counting rules that enabled them to show that the Agrobacterium tumefaciens $16 \mathrm{~S}$ rRNA sequence, their representative of the $\alpha$ group of purple bacteria, was the best candidate for ancestor. $A$. tumefaciens possesses a cytochrome $c$ (Van Beeumen et al., 1980) that is not notably close in sequence to any mitochondrial cytochrome $c$ (Table 2). The Woese interpretation needs to postulate that $16 \mathrm{~S}$ rRNA has evolved much faster in all mitochondria than in bacteria, which is the opposite to the situation for cytochrome $c$ indicated by the values given in Table 2 .

Meyer et al. (1986) have discussed the difficulties that exist in deducing phylogenetic trees from sequence similarities. They suggest that there are finite structural limitations on the variation of a macromolecule (be it $16 \mathrm{~S}$ rRNA or cytochrome $c$ ) that performs a particular function. The result is that evolutionary divergence can only go as far as this limit if function is to be retained, and as this limit is approached an increasing proportion of the acceptable changes will be convergent ones. 


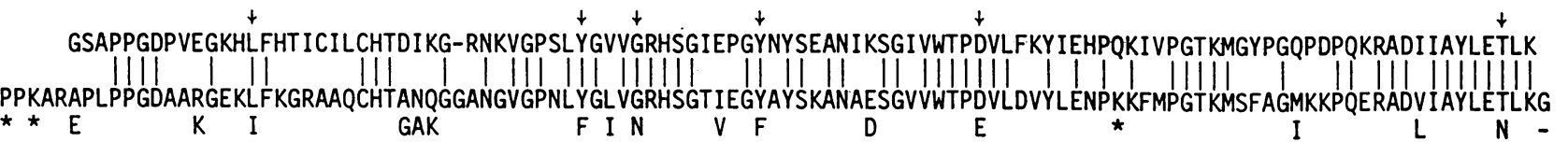

Fig. 2. Amino acid sequences of (1) Rhodopseudomonas globiformis cytochrome $c_{2}$ and (2) Crithidia fasciculata mitochondrial cytochrome c-558 (Hill \& Pettigrew, 1975)

Residues identical between the Rps. globiformis and C. fasciculata sequences are marked $\mid$. The 16 amino acid residues and the gap that distinguish the protein of Crithidia oncopelti (Pettigrew et al., 1975) from that of $C$. fasciculata are shown under sequence (2). The six positions in which the bacterial protein is like that from $C$. fasciculata but different to $C$. oncopelti are marked $\downarrow$. In sequence (2) the residues marked * are post-translationally modified. The mitochondrial cytochrome $c-558$ from Euglena gracilis can be aligned with sequence (1) without the need to postulate any internal deletions or insertions.

Normal divergence could resume if some of the structural constraints were withdrawn by the function of the macromolecule changing. We suggest that, even though the genes for the cytochromes $c$ shown in Table 2 all have a common origin, the amount of difference between almost all of them has reached this limit, and that it is not possible to deduce a phylogenetic tree relating sequences that have reached this steady state of balanced divergence and convergence.

There is also the statistical expectation that, within a set of sequences that has reached this steady state, some pairs would have drifted closer to each other than the average separation. The problem then becomes to decide which of the 'more similar' values in Table 2 represent genuine evolutionary affinity, and which are examples of convergence. We suggest that the similarity in sequence that we can see between the cytochrome $c$ from the zooflagellate protozoon $C$. fasciculata and the uncommon bacterium from an exotic habitat, Rps. globiformis (Fig. 2), is a chance event of this nature, and gives us no special information about the postulated mitochondrial ancestor.

Our convergence hypothesis is supported by a consideration of the sequence of the cytochrome $c$ of Crithidia oncopelti (Pettigrew et al., 1975), which is $86 \%$ identical with that from $C$. fasciculata. We presume that this difference between similar organisms is the result of divergence. However, the Rps. globiformis sequence is only $54 \%$ identical with that from $C$. oncopelti sequence, as compared with $59 \%$ identity with that from $C$. fasciculata. There are 16 differences between the two crithidial proteins, but in six of these positions the Rps. globiformis protein is like that from $C$. fasciculata. This difference of $5 \%$ provides a lower estimate of the amount of convergence that has occurred in the cytochrome $c$.

We believe that it is useful to investigate the electron-transport chains and metabolism of present-day bacteria, and to compare them with mitochondria (Whatley, 1981), and then by analogy consider the likely properties of organisms that may in the remote past have been assimilated by other organisms to form eukaryotic cells. However, any reconstruction that we attempt will be an allegory, and no studies of sequences of macromolecules from present-day organisms will enable a reliable description of these mitochondrial ancestors to be made.

In a similar context, Perutz (1986), discussing possible explanations for the discovery of a haemoglobin-like protein in a bacterium (Wakabayashi et al., 1986), writes 'Is this an example of divergent or convergent evolution, or of gene transfer from eukaryotes? Who can guess? We were not there when it happened.'

The work was supported by grants from the Medical Research Council and the Science Research Council to R.P.A., and from the National Institutes of Health (GM 21277) to M. A. C. We thank Margaret Daniel and Lesley McLellan for skilled and enthusiastic technical assistance. We thank Dr. G. R. Drapeau for the gift of the Pseudomonas fragi proteinase.

\section{REFERENCES}

Ambler, R. P. \& Wynn, M. (1973) Biochem. J. 131, 485-498

Ambler, R. P., Meyer, T. E. \& Kamen, M. D. (1976) Proc. Natl. Acad. Sci. U.S.A. 73, 472-475

Ambler, R. P., Daniel, M., Hermoso, J., Meyer, T. E., Bartsch, R. G. \& Kamen, M. D. (1979a) Nature (London) 278, 659-660

Ambler, R. P., Meyer, T. E. \& Kamen, M. D. (1979b) Nature (London) 278, 661-662

Ambler, R. P., Daniel, M., Meyer, T. E., Bartsch, R. G. \& Kamen, M. D. (1979c) Biochem. J. 177, 819-823

Ambler, R. P., Daniel, M., Melis, K. \& Stout, C. D. (1984) Biochem. J. 222, 217-227

Barnabas, J., Schwartz, R. M. \& Dayhoff, M. O. (1982) Origins Life 12, 81-91

Daldal, F., Cheng, S., Applebaum, J., Davidson, E. \& Prince, R. C. (1986) Proc. Natl. Acad. Sci. U.S.A. 83, 2012-2016

Dayhoff, M. O. (1983) Precambrian Res. 20, 299-318

Dayhoff, M. O. \& Schwartz, R: M. (1981) Ann. N.Y. Acad. Sci. 361, 92-104

Dickerson, R. E. (1980) Nature (London) 283, 210-212

Drapeau, G. R. (1980) J. Biol. Chem. 255, 839-840

Fox, G. E., Pechman, K. J. \& Woese, C. R. (1977) Int. J. Syst. Bacteriol. 27, 44-57

Hill, G. C. \& Pettigrew, G. W. (1975) Eur. J. Biochem. 57, 265-270

Imhoff, J. F., Trüper, H. G. \& Pfennig, N. (1984) Int. J. Syst. Bacteriol. 34, 340-343

Kilmer, J. (1913) Poetry 2, 160

Meatyard, B. T. \& Boulter, D. (1974) Phytochemistry 13, 2777-2782

Meyer, T. E. \& Kamen, M. D. (1982) Adv. Protein Chem. 35, 105-212

Meyer, T. E., Cusanovich, M. A. \& Kamen, M. D. (1986) Proc. Natl. Acad. Sci. U.S.A. 83, 217-220

Perutz, M. F. (1986) Nature (London) 322, 405

Pettigrew, G. W., Leaver, J. L., Meyer, T. E. \& Ryle, A. P. (1975) Biochem. J. 147, 291-302

Pfennig, N. (1974) Arch. Microbiol. 100, 197-206

Tanaka, Y., Fukumori, Y. \& Yamanaka, T. (1982) Biochim. Biophys. Acta 707, 14-20 
Van Beeumen, J., Tempst, P., Stevens, P., Bral, D., Van Damme, J. \& De Ley, J. (1980) Protides Biol. Fluids 28, 69-74

Wakabayashi, S., Matsubara, H. \& Webster, D. A. (1986) Nature (London) 322, 481-483

Whatley, F. R. (1981) Ann. N.Y. Acad. Sci. 361, 330340

Received 16 February 1987; accepted 6 May 1987
Woese, C. R., Stackebrandt, E., Weisburg, W. G., Paster, B. J., Madigan, M. T., Fowler, V. J., Hahn, C. M., Blanz, P., Gupta, R., Nealson, K. H. \& Fox, G. E. (1984) Syst. Appl. Microbiol. 5, 315-326

Woolley, K. (1987) Eur. J Biochem., in the press

Yang, D., Oyaizu, Y., Oyaizu, H., Olsen, G. J. \& Woese, C. R. (1985) Proc. Natl. Acad. Sci. U.S.A. 82, 4443-4447 